\title{
REVIEW: Treatment of Hypothyroidism with Combinations of Levothyroxine plus Liothyronine
}

\author{
Héctor F. Escobar-Morreale, José I. Botella-Carretero, Francisco Escobar del Rey, and \\ Gabriella Morreale de Escobar \\ Department of Endocrinology, Hospital Ramón y Cajal (H.F.E.-M., J.I.B.-C.) and Instituto de Investigaciones Biomédicas, \\ Consejo Superior de Investigaciones Científicas y Universidad Autónoma de Madrid (F.E.d.R., G.M.d.E.), 28034 Madrid, \\ Spain
}

\begin{abstract}
Context: Combined infusion of levothyroxine plus liothyronine, as opposed to levothyroxine alone, is the only way of restoring the concentrations of circulating $\mathrm{TSH}, \mathrm{T}_{4}$, and $\mathrm{T}_{3}$ as well as those of both $\mathrm{T}_{4}$ and $\mathrm{T}_{3}$ in all tissues of thyroidectomized rats. Considering the substantial differences in thyroid hormone secretion, transport, and metabolism between rats and humans, whether or not combined levothyroxine plus liothyronine replacement therapy has advantages over treatment with levothyroxine alone in hypothyroid patients is still questioned.
\end{abstract}

Evidence Acquisition: We conducted a systematic review of all the published controlled studies comparing treatment with levothyroxine alone with combinations of levothyroxine plus liothyronine in hypothyroid patients, identified through the Entrez-PubMed search engine.

Evidence Synthesis: Nine controlled clinical trials were identified that compared treatment with levothyroxine alone and treatment with combinations of levothyroxine plus liothyronine and included a sufficient number of adult hypothyroid patients to yield meaningful results. In only one study did the combined therapy appear to have beneficial effects on the mood, quality of life, and psychometric performance of the patients over levothyroxine alone. These results have not been confirmed by later studies using either $\mathrm{T}_{3}$ substitution protocols or approaches with fixed combinations of levothyroxine plus liothyronine, including those based on the physiological proportion in which $\mathrm{T}_{3}$ and $\mathrm{T}_{4}$ are secreted by the human thyroid. However, in some of these studies the patients preferred levothyroxine plus liothyronine combinations, for reasons not explained by changes in the psychological and psychometric tests employed. Yet patients' preference should be balanced against the possibility of adverse events resulting from the addition of liothyronine to levothyroxine, even in the small doses used in these studies.

Conclusions: Until clear advantages of levothyroxine plus liothyronine are demonstrated, the administration of levothyroxine alone should remain the treatment of choice for replacement therapy of hypothyroidism. (J Clin Endocrinol Metab 90: 4946-4954, 2005)
A T PRESENT, SODIUM levothyroxine is the preparation of choice to restore well-being and euthyroidism in hypothyroid patients (1-3). The latter is believed to occur when serum TSH returns to the reference range (2), with serum TSH concentrations usually used to monitor levothyroxine therapy. Reliance on circulating TSH is supported by many years of experience, and most patients are satisfied with the results, but it implies assumptions that are not supported by direct evidence.

First, although approximately $80 \%$ of the $\mathrm{T}_{3}$ circulating in blood is originated by peripheral 5 -deiodination of the $\mathrm{T}_{4}$ secreted by the thyroid gland, as much as $20 \%$ is secreted directly by the gland (4), suggesting a physiological role for the latter fraction. When patients are given levothyroxine alone, it is assumed that peripheral conversion of $T_{4}$ to $T_{3}$ provides the exact amount of $T_{3}$ needed by each particular tissue or organ that is usually provided by the missing thyroid secretion.

But the scarce evidence available for man does not support this. Hypothyroid patients on levothyroxine replacement

First Published Online May 31, 2005

Abbreviations: PBI, Protein-bound iodine; QoL, quality of life; TBG, thyroid-binding globulin.

JCEM is published monthly by The Endocrine Society (http://www. endo-society.org), the foremost professional society serving the endocrine community. therapy have higher serum $\mathrm{T}_{4}$ levels when serum TSH and $\mathrm{T}_{3}$ concentrations are similar to those of euthyroid controls (5). In as many as $25-32 \%$ of hypothyroid patients on levothyroxine therapy, serum $\mathrm{T}_{4}$ has to reach the upper limit of the normal range, or even exceed it, to normalize serum TSH and its normal response to TSH-releasing hormone $(6,7)$. These findings suggest that the levothyroxine doses needed to normalize serum TSH in hypothyroid patients are relatively supraphysiological, possibly to compensate for the absence of the fraction of circulating $\mathrm{T}_{3}$ secreted directly by the thyroid.

Second, TSH is widely used to monitor levothyroxine replacement therapy $(1-3,6)$, assuming implicitly that its level within the normal range indicates euthyroidism in all tissues of hypothyroid patients. Serum TSH levels, however, only reflect the feedback effect of thyroid hormones at the hypothalamic-pituitary level. In patients on long-term replacement with levothyroxine presenting with biochemical abnormalities suggestive of hyperthyroidism, free $\mathrm{T}_{4}$ was raised in $85 \%$ of them, whereas an undetectable serum TSH was present in only $67 \%$ (8). Moreover, athyreotic patients present a differential end-organ responsiveness to suboptimal thyroid hormone concentrations (9). It is thus unlikely that a single end-point of thyroid hormone action, such as serum TSH, accurately reflects the thyroid hormone concentrations in all tissues and organs. 


\section{Combined Levothyroxine plus Liothyronine Treatment for Hypothyroidism in Animal Models}

We have conducted a series of animal studies to evaluate whether replacement therapy with levothyroxine alone actually resulted in euthyroidism (10-13). Thyroidectomized rats received continuous sc infusions of levothyroxine, synthetic $\mathrm{T}_{3}$ (liothyronine), or combinations of levothyroxine plus liothyronine. Samples of plasma and most tissues were assayed for thyroid hormone measurements, and types 1, 2, and 3 deiodinase activities were measured in several tissues (Fig. 1). Tissue euthyroidism was declared when the concentrations of both $\mathrm{T}_{4}$ and $\mathrm{T}_{3}$ were within the normal range found in intact euthyroid animals infused with placebo.

We found in Refs. 10-13 that: 1) despite a wide range of doses infused (from 0.2-8.0 $\mu \mathrm{g}$ levothyroxine/100 $\mathrm{g}$ body weight per day and from 0.25-2.0 $\mu \mathrm{g}$ liothyronine/100 $\mathrm{g}$ body weight per day), neither levothyroxine nor liothyronine alone restored euthyroidism (Tables 1 and 2); 2) combinations of levothyroxine plus liothyronine, however, based on the amounts and proportions of $\mathrm{T}_{4}$ and $\mathrm{T}_{3}$ present in the rat thyroidal secretion, did ensure euthyroidism (Table 3); 3) with the levothyroxine dose that normalized plasma TSH, most tissues still had $\mathrm{T}_{3}$ concentrations below the normal range (Table 1$) ; 4$ ) when levothyroxine plus liothyronine combinations were infused, the levothyroxine needed to normalize serum TSH was almost half the dose required with levothyroxine alone (Tables 1 and 3); 5) the mechanisms involved in the regulation of thyroid hormone concentrations were tissue specific, and so was the efficiency of the homeostasis of tissue $\mathrm{T}_{3}$ concentrations (Tables 1-3); 6) when levothyroxine alone was used for replacement therapy, the cerebral cortex was extremely efficient in maintaining normal $\mathrm{T}_{3}$ concentrations and was virtually independent from changes in serum concentrations of $\mathrm{T}_{4}$ and $\mathrm{T}_{3}$ (Table 1); and 7) this excellent homeostasis of brain $T_{3}$ levels was lost when liothyronine alone was infused (Table 2).

These conclusions cast doubts upon replacement therapy in humans with levothyroxine alone (11), because it might not be able to restore euthyroidism in all tissues of hypothyroid patients. Normalization of serum TSH, the usual marker of euthyroidism during treatment, might not ensure normal $\mathrm{T}_{3}$ concentrations in some tissues.

\section{Infusion of T4, T3, T4 + T3, or placebo, using osmotic minipumps (5-6 rats / group)}

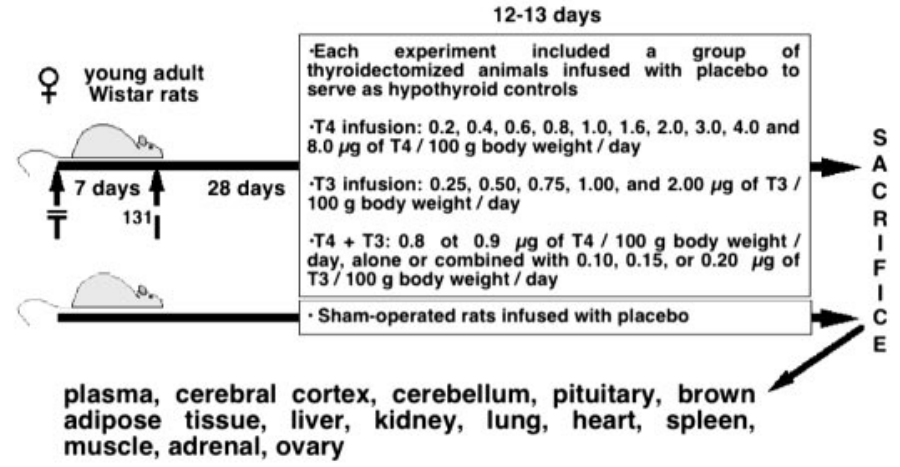

FIG. 1. Experimental design of our studies in thyroidectomized rats infused with levothyroxine alone, liothyronine, or levothyroxine plus liothyronine.
We therefore hypothesized that a combined treatment of levothyroxine plus liothyronine might be advantageous for hypothyroid patients, compared with levothyroxine alone (11). Based on our results in the rat, we made several recommendations regarding the ideal thyroid hormone preparation (11): 1) it should contain levothyroxine and liothyronine in a molar proportion of $14: 1$ and deliver into the circulation approximately $100 \mu \mathrm{g} \mathrm{T}_{4}$ and $6 \mu \mathrm{g} \mathrm{T}_{3}$ per day, thus mimicking human thyroid secretion (4), and 2) the route of administration should warrant a constant steady supply of levothyroxine and liothyronine, by means of enteric, im, or transdermal sustained-release preparations, at least for the $\mathrm{T}_{3}$ component. However, most of the studies conducted in hypothyroid patients after the publication of our data have ignored these recommendations, despite being rapidly adopted by other experts in the field (14).

There are substantial differences between rats and humans in thyroid hormone secretion, transport, and metabolism. The molar $\mathrm{T}_{4}: \mathrm{T}_{3}$ ratio in thyroid secretion has been calculated as $14: 1$ in adult man (4), whereas the corresponding mean value obtained for the adult male rat is approximately 6:1 (15-18). In humans, thyroid-binding globulin (TBG) is the principal serum transport protein for thyroid hormones, whereas only a small proportion circulates bound to transthyretin and albumin. Binding to TBG may serve as a circulating buffer that might partially alleviate the thyroid when exposed to sudden increases in the requirements of these hormones. In rat serum, transthyretin is the dominant thyroid hormone-binding protein, the concentration of TBG being extremely low in adults, approximately $2 \%$ of that circulating in humans $(19,20)$. Thyroid hormones' metabolism is less buffered by plasma proteins than it is in man, with a greater proportion circulating as free $T_{4}$ and free $T_{3}(21,22)$. This may contribute to explain the need of a higher proportion of $T_{3}$ with respect to $T_{4}$ secreted by the rat thyroid.

Moreover, the regulation of tissue thyroid hormone concentrations involve deiodinative and nondeiodinative pathways of $\mathrm{T}_{4}$ and $\mathrm{T}_{3}$ metabolism and factors regulating the uptake and exit of iodothyronines into organs and tissues (23-27), and these mechanisms may be both tissue and species specific.

These differences between animals and humans ought to be considered before extending the rat findings to human physiology and, especially, to the issue of treatment with thyroid hormone preparations in hypothyroid patients.

\section{Combined Levothyroxine plus Liothyronine Treatment for Hypothyroidism in Humans}

There are few studies comparing levothyroxine replacement therapy with treatments using combinations of levothyroxine plus liothyronine (Table 4). Taylor and his coworkers observed that patients treated with levothyroxine alone had increased plasma protein-bound iodine (PBI) values compared with healthy euthyroid controls. They reported in 1970 (28) that patients' PBIs were comparable to those of euthyroid subjects when given tablets containing 50 $\mu \mathrm{g}$ levothyroxine plus $15 \mu \mathrm{g}$ liothyronine (Fig. 2), with maintenance of clinical euthyroidism.

Some months later, Smith et al. (29) published the first 
TABLE 1. Schematic representation of plasma concentrations of $\mathrm{T}_{4}, \mathrm{~T}_{3}$, and TSH and tissue levels of $\mathrm{T}_{4}$ and $\mathrm{T}_{3}$ in thyroidectomized rats infused with different doses of levothyroxine with respect to age- and sex-matched controls

\begin{tabular}{|c|c|c|c|c|c|c|c|c|c|c|c|c|c|c|c|c|c|c|c|c|c|c|c|c|c|c|c|c|c|c|}
\hline & \multicolumn{30}{|c|}{ Dose of $\mathrm{T}_{4}(\mu \mathrm{g} / 100 \mathrm{~g} \cdot \mathrm{d})$} \\
\hline & \multicolumn{3}{|c|}{0.2} & \multicolumn{3}{|c|}{0.4} & \multicolumn{3}{|c|}{0.6} & \multicolumn{3}{|c|}{0.8} & \multicolumn{3}{|c|}{1.0} & \multicolumn{3}{|c|}{1.6} & \multicolumn{3}{|c|}{2.0} & \multicolumn{3}{|c|}{3.0} & \multicolumn{3}{|c|}{4.0} & \multicolumn{3}{|c|}{8.0} \\
\hline & $\overline{\mathrm{T}_{4}}$ & $\mathrm{~T}_{3}$ & $\mathrm{TSH}$ & $\overline{\mathrm{T}_{4}}$ & $\mathrm{~T}_{3}$ & $\mathrm{TSH}$ & $\mathrm{T}_{4}$ & $\mathrm{~T}_{3}$ & TSH & $\overline{\mathrm{T}_{4}}$ & $\mathrm{~T}_{3}$ & $\mathrm{TSH}$ & $\overline{\mathrm{T}_{4}}$ & $\mathrm{~T}_{3}$ & TSH & $\overline{\mathrm{T}_{4}}$ & $\mathrm{~T}_{3}$ & TSH & $\overline{\mathrm{T}_{4}}$ & $\mathrm{~T}_{3}$ & $\mathrm{TSH}$ & $\overline{\mathrm{T}_{4}}$ & $\mathrm{~T}_{3}$ & $\mathrm{TSH}$ & $\overline{\mathrm{T}_{4}}$ & $\mathrm{~T}_{3}$ & $\mathrm{TSH}$ & $\overline{\mathrm{T}_{4}}$ & $\mathrm{~T}_{3}$ & $\mathrm{TSH}$ \\
\hline Plasma & $\downarrow$ & $\downarrow$ & $\uparrow$ & $\downarrow$ & $\downarrow$ & $\uparrow$ & $=$ & $\downarrow$ & $\uparrow$ & $=$ & $\downarrow$ & $\uparrow$ & $=$ & $=$ & $\uparrow$ & $\uparrow$ & $=$ & $=$ & $\uparrow$ & $\uparrow$ & $\downarrow$ & $\uparrow$ & $\uparrow$ & $\downarrow$ & $\uparrow$ & $\uparrow$ & $\downarrow$ & $\uparrow$ & $\uparrow$ & $\downarrow$ \\
\hline $\begin{array}{c}\text { Cerebral } \\
\text { cortex }\end{array}$ & $\downarrow$ & $\downarrow$ & & $\downarrow$ & $=$ & & $\downarrow$ & $=$ & & $\downarrow$ & $=$ & & $\uparrow$ & $=$ & & $\uparrow$ & $\uparrow$ & & $\uparrow$ & $=$ & & $\uparrow$ & $=$ & & $\uparrow$ & $=$ & & $\uparrow$ & $=$ & \\
\hline Cerebellum & $\downarrow$ & $\downarrow$ & & $\downarrow$ & $\downarrow$ & & $=$ & $\downarrow$ & & $\uparrow$ & $=$ & & $=$ & $=$ & & $\uparrow$ & $=$ & & $=$ & $=$ & & $\uparrow$ & $=$ & & $\uparrow$ & $\uparrow$ & & $\uparrow$ & $\uparrow$ & \\
\hline Pituitary & $\downarrow$ & $\downarrow$ & & $\downarrow$ & $\downarrow$ & & $=$ & $\downarrow$ & & $\uparrow$ & $\downarrow$ & & $=$ & $=$ & & $\uparrow$ & $=$ & & $=$ & $=$ & & $=$ & $=$ & & $\uparrow$ & $\uparrow$ & & $\uparrow$ & $\uparrow$ & \\
\hline BAT & & $\downarrow$ & & & $=$ & & & $=$ & & & $=$ & & & $=$ & & & $\downarrow$ & & & $=$ & & & $=$ & & & $=$ & & & $=$ & \\
\hline Liver & $\downarrow$ & $\downarrow$ & & $\downarrow$ & $\downarrow$ & & $\downarrow$ & $\downarrow$ & & $\downarrow$ & $\downarrow$ & & $=$ & $\downarrow$ & & $\uparrow$ & $=$ & & $\uparrow$ & $=$ & & $\uparrow$ & $=$ & & $\uparrow$ & $\uparrow$ & & $\uparrow$ & $\uparrow$ & \\
\hline Kidney & $\downarrow$ & $\downarrow$ & & $\downarrow$ & $\downarrow$ & & $\downarrow$ & $\downarrow$ & & $\downarrow$ & $\downarrow$ & & $=$ & $\downarrow$ & & $\uparrow$ & $=$ & & $\uparrow$ & $\uparrow$ & & $\uparrow$ & $\uparrow$ & & $\uparrow$ & $\uparrow$ & & $\uparrow$ & $\uparrow$ & \\
\hline Lung & $\downarrow$ & 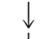 & & $\downarrow$ & $\downarrow$ & & $=$ & $\downarrow$ & & $=$ & $\downarrow$ & & $=$ & $\downarrow$ & & $\uparrow$ & $\downarrow$ & & $\uparrow$ & $=$ & & $\uparrow$ & $\uparrow$ & & $\uparrow$ & $\uparrow$ & & $\uparrow$ & $\uparrow$ & \\
\hline Heart & $\downarrow$ & $\downarrow$ & & $\downarrow$ & $\downarrow$ & & $=$ & $\downarrow$ & & $=$ & $\downarrow$ & & $=$ & $\downarrow$ & & $=$ & $\downarrow$ & & $\uparrow$ & $=$ & & $\uparrow$ & $\uparrow$ & & $\uparrow$ & $\uparrow$ & & $\uparrow$ & $\uparrow$ & \\
\hline Muscle & $\downarrow$ & $\downarrow$ & & $=$ & $\downarrow$ & & $=$ & $\downarrow$ & & $\uparrow$ & $=$ & & $\uparrow$ & $=$ & & $\uparrow$ & $\uparrow$ & & $\uparrow$ & $\uparrow$ & & $\uparrow$ & $=$ & & $\uparrow$ & $\uparrow$ & & $\uparrow$ & $\uparrow$ & \\
\hline Spleen & $\downarrow$ & 1 & & $\downarrow$ & $\downarrow$ & & $=$ & $\downarrow$ & & $=$ & $=$ & & $=$ & $\downarrow$ & & $\uparrow$ & $\uparrow$ & & $\uparrow$ & $=$ & & $\uparrow$ & $\uparrow$ & & $\uparrow$ & $\uparrow$ & & $\uparrow$ & $\uparrow$ & \\
\hline Adrenal & $\downarrow$ & $\downarrow$ & & $\downarrow$ & $\downarrow$ & & $=$ & $\downarrow$ & & $=$ & $\downarrow$ & & $=$ & $\downarrow$ & & $\uparrow$ & $\downarrow$ & & $\uparrow$ & $=$ & & $=$ & $\downarrow$ & & $\uparrow$ & $=$ & & $\uparrow$ & $=$ & \\
\hline Ovary & $\downarrow$ & $\downarrow$ & & $\downarrow$ & $\downarrow$ & & $\downarrow$ & $\downarrow$ & & $=$ & $\downarrow$ & & $=$ & $\downarrow$ & & $=$ & $\downarrow$ & & $=$ & $=$ & & $=$ & $=$ & & $=$ & $=$ & & $=$ & $=$ & \\
\hline
\end{tabular}

The symbols represent the comparison of the mean values of the levothyroxine-infused rats with control rats infused with placebo. $=$, No statistically significant differences; $\downarrow$, low levels as compared with controls, with at least $P<0.05$; $\uparrow$, elevated levels as compared with controls, with at least $P<0.05$. BAT, Brown adipose tissue. [Redrawn with permission from data published in $\mathrm{H}$. F. Escobar-Morreale et al.: $J$ Clin Invest $96: 2828,1995(10)$.

study comparing levothyroxine therapy with combined levothyroxine plus liothyronine treatment. Using a doubleblinded, crossover design, they assigned 87 patients to receive their usual number of tablets (two or three), containing either $100 \mu \mathrm{g}$ levothyroxine or $80 \mu \mathrm{g}$ levothyroxine plus 20 $\mu \mathrm{g}$ liothyronine, with treatments rotated after 2 months.

Adverse effects (palpitations, irritability, nervousness, dizziness, and tremor) were more frequent during combined levothyroxine plus liothyronine treatment. Thirty-three percent preferred levothyroxine tablets, $18.4 \%$ preferred levothyroxine plus liothyronine tablets, whereas $48.3 \%$ showed no preference. Adverse effects influenced patients' preference (29).

With levothyroxine plus liothyronine, the plasma PBI and the free $T_{4}$ index decreased, whereas the $T_{3}$-resin uptake values were not altered (29). They concluded that "the shortcomings of combined therapy suggested overall advantages of thyroxine for replacement therapy" (29). We know nowadays that all their patients were overtreated, with the adverse effects using the combinations being easily explained by the addition of $40-60 \mu \mathrm{g}$ liothyronine to an already excessive levothyroxine dose.

The interest for a combined levothyroxine plus liothyronine therapy declined until the late 1990s, when our animal studies were published (10-13). Although actually ignoring our recommendations for man (11), Bunevicius et al. (30) published in 1999 their favorable experience with combined levothyroxine plus liothyronine replacement therapy in 33 hypothyroid patients, 31 women and two men, of whom 17 were thyroidectomized thyroid cancer patients and 16 had chronic autoimmune thyroiditis.

The study was a randomized, double-blinded crossover trial (30), using what has been named a $\mathrm{T}_{3}$ substitution approach (31), substitution of a fixed amount of liothyronine for

TABLE 2. Schematic representation of plasma concentrations of $\mathrm{T}_{4}, \mathrm{~T}_{3}$, and TSH and tissue levels of $\mathrm{T}_{4}$ and $\mathrm{T}_{3}$ in thyroidectomized rats infused with different doses of liothyronine with respect to age- and sex-matched controls

\begin{tabular}{|c|c|c|c|c|c|c|c|c|c|c|c|c|c|c|c|}
\hline & \multicolumn{15}{|c|}{ Dose of $\mathrm{T}_{3}(\mu \mathrm{g} / 100 \mathrm{~g} \cdot \mathrm{d})$} \\
\hline & \multicolumn{3}{|c|}{0.25} & \multicolumn{3}{|c|}{0.50} & \multicolumn{3}{|c|}{0.75} & \multicolumn{3}{|c|}{1.0} & \multicolumn{3}{|c|}{2.0} \\
\hline & $\overline{\mathrm{T}_{4}}$ & $\mathrm{~T}_{3}$ & TSH & $\overline{\mathrm{T}_{4}}$ & $\mathrm{~T}_{3}$ & TSH & $\overline{\mathrm{T}_{4}}$ & $\mathrm{~T}_{3}$ & TSH & $\overline{\mathrm{T}_{4}}$ & $\mathrm{~T}_{3}$ & TSH & $\overline{\mathrm{T}_{4}}$ & $\mathrm{~T}_{3}$ & $\overline{\mathrm{TSH}}$ \\
\hline Plasma & $\downarrow$ & $=$ & $\uparrow$ & $\downarrow$ & $\uparrow \uparrow$ & $\downarrow$ & $\downarrow$ & $\uparrow$ & $\downarrow$ & $\downarrow$ & $\uparrow \uparrow$ & $\downarrow$ & $\downarrow$ & $\uparrow$ & $\downarrow$ \\
\hline Cerebral cortex & $\downarrow$ & $\downarrow$ & & $\downarrow$ & $=$ & & $\downarrow$ & $=$ & & $\downarrow$ & $=$ & & $\downarrow$ & $\uparrow$ & \\
\hline Cerebellum & $\downarrow$ & $=$ & & $\downarrow$ & $=$ & & $\downarrow$ & $\uparrow$ & & $\downarrow$ & $\uparrow$ & & $\downarrow$ & $\uparrow$ & \\
\hline Pituitary & $\downarrow$ & $\downarrow$ & & $\downarrow$ & $=$ & & $\downarrow$ & $=$ & & $\downarrow$ & $\uparrow$ & & $\downarrow$ & $\uparrow$ & \\
\hline BAT & $\downarrow$ & $\downarrow$ & & $\downarrow$ & $\downarrow$ & & $\downarrow$ & $=$ & & $\downarrow$ & $=$ & & $\downarrow$ & $=$ & \\
\hline Liver & $\downarrow$ & $\downarrow$ & & $\downarrow$ & $\uparrow$ & & $\downarrow$ & $\uparrow$ & & $\downarrow$ & $\uparrow$ & & $\downarrow$ & $\uparrow$ & \\
\hline Kidney & $\downarrow$ & $\downarrow$ & & $\downarrow$ & $=$ & & $\downarrow$ & $\uparrow$ & & $\downarrow$ & $\uparrow$ & & $\downarrow$ & $\uparrow$ & \\
\hline Lung & $\downarrow$ & $=$ & & $\downarrow$ & $\uparrow$ & & $\downarrow$ & $\uparrow$ & & $\downarrow$ & $\uparrow$ & & $\downarrow$ & $\uparrow$ & \\
\hline Heart & $\downarrow$ & $\downarrow$ & & $\downarrow$ & $\uparrow$ & & $\downarrow$ & $\uparrow$ & & $\downarrow$ & $\uparrow$ & & $\downarrow$ & $\uparrow$ & \\
\hline Muscle & $\downarrow$ & $=$ & & $\downarrow$ & $\uparrow$ & & $\downarrow$ & $\uparrow$ & & $\downarrow$ & $\uparrow$ & & $\downarrow$ & $\uparrow$ & \\
\hline Spleen & $\downarrow$ & $=$ & & $\downarrow$ & $\uparrow$ & & $\downarrow$ & $\uparrow$ & & $\downarrow$ & $\uparrow$ & & $\downarrow$ & $\uparrow$ & \\
\hline Adrenal & $\downarrow$ & $=$ & & $\downarrow$ & $\uparrow$ & & $\downarrow$ & $\uparrow$ & & $\downarrow$ & $\uparrow$ & & $\downarrow$ & $\uparrow$ & \\
\hline Ovary & $\downarrow$ & $=$ & & $\downarrow$ & $=$ & & $\downarrow$ & $\uparrow$ & & $\downarrow$ & $\uparrow$ & & $\downarrow$ & $\uparrow$ & \\
\hline
\end{tabular}

The symbols represent the comparison of the mean values of the liothyronine-infused rats with control rats infused with placebo. $=$, No statistically significant differences; $\downarrow$, low levels as compared with controls, with at least $P<0.05$; $\uparrow$, elevated levels as compared with controls, with at least $P<0.05$. BAT, Brown adipose tissue. [Represented with permission from data published in H. F. Escobar-Morreale et al.: Biochimie (Paris) 81:453, 1999 (13). ${ }^{\odot}$ Elsevier.] 
TABLE 3. Schematic representation of the changes with respect to intact control rats in the plasma concentrations of $\mathrm{T}_{4}, \mathrm{~T}_{3}$, and $\mathrm{TSH}$ and tissue levels of $\mathrm{T}_{4}$ and $\mathrm{T}_{3}$ of thyroidectomized rats infused with different doses of levothyroxine, alone or in combination with different doses of liothyronine

\begin{tabular}{|c|c|c|c|c|c|c|c|c|c|c|c|c|c|c|c|c|c|c|c|c|c|c|c|c|}
\hline & \multicolumn{12}{|c|}{$0.80 \mu \mathrm{g} \mathrm{T}_{4}$} & \multicolumn{12}{|c|}{$0.90 \mu \mathrm{g} \mathrm{T}_{4}$} \\
\hline & \multicolumn{3}{|c|}{ No $T_{3}$} & \multicolumn{3}{|c|}{$0.10 \mu \mathrm{g} \mathrm{T}_{3}$} & \multicolumn{3}{|c|}{$0.15 \mu \mathrm{g} \mathrm{T}_{3}$} & \multicolumn{3}{|c|}{$0.20 \mu \mathrm{g} \mathrm{T}_{3}$} & \multicolumn{3}{|c|}{ No $T_{3}$} & \multicolumn{3}{|c|}{$0.10 \mu \mathrm{g} \mathrm{T}_{3}$} & \multicolumn{3}{|c|}{$0.15 \mu \mathrm{g} \mathrm{T}_{3}$} & \multicolumn{3}{|c|}{$0.20 \mu \mathrm{g} \mathrm{T}_{3}$} \\
\hline & $\mathrm{T}_{4}$ & $\mathrm{~T}_{3}$ & $\mathrm{TSH}$ & $\mathrm{T}_{4}$ & $\mathrm{~T}_{3}$ & $\mathrm{TSH}$ & $\mathrm{T}_{4}$ & $\mathrm{~T}_{3}$ & $\mathrm{TSH}$ & $\mathrm{T}_{4}$ & $\mathrm{~T}_{3}$ & $\mathrm{TSH}$ & $\mathrm{T}_{4}$ & $\mathrm{~T}_{3}$ & $\mathrm{TSH}$ & $\mathrm{T}_{4}$ & $\mathrm{~T}_{3}$ & $\mathrm{TSH}$ & $\mathrm{T}_{4}$ & $\mathrm{~T}_{3}$ & $\mathrm{TSH}$ & $\mathrm{T}_{4}$ & $\mathrm{~T}_{3}$ & $\mathrm{TSH}$ \\
\hline Plasma & $=$ & $\downarrow$ & $\uparrow$ & $=$ & $=$ & $\uparrow$ & $=$ & $=$ & $\uparrow$ & $=$ & $=$ & $=$ & $=$ & $\downarrow$ & $\uparrow$ & $=$ & $=$ & $\uparrow$ & $=$ & $=$ & $={ }^{a}$ & $=$ & $=$ & $=$ \\
\hline Cerebral cortex & $=$ & $=$ & $a$ & $=$ & $=$ & & $=$ & $=$ & & $=$ & $\uparrow$ & & $=$ & $=$ & $a$ & $=$ & $\uparrow$ & & $=$ & $=$ & $a$ & $=$ & $=$ & \\
\hline Pituitary & $=$ & $\downarrow$ & & $=$ & $\downarrow$ & & $=$ & $=$ & $a$ & $=$ & $=$ & $a$ & $=$ & $\downarrow$ & & $=$ & $=$ & $a$ & $=$ & $=$ & & $=$ & $=$ & \\
\hline Cerebellum & $=$ & $=$ & $a$ & $=$ & $=$ & $a$ & $=$ & $=$ & $a$ & $=$ & $=$ & $a$ & $=$ & $\downarrow$ & & $=$ & $=$ & $a$ & $=$ & $=$ & $a$ & $=$ & $=$ & $a$ \\
\hline BAT & $=$ & $=$ & $a$ & $\uparrow$ & $=$ & & $=$ & $=$ & $a$ & $=$ & $=$ & $a$ & $=$ & $\downarrow$ & & $=$ & $\uparrow$ & & $=$ & $=$ & & $=$ & $=$ & \\
\hline Liver & $=$ & $\downarrow$ & & $=$ & $=$ & $a$ & $\downarrow$ & $=$ & & $=$ & $=$ & $a$ & $=$ & $\downarrow$ & & $\downarrow$ & $\downarrow$ & & $=$ & $=$ & $a$ & $=$ & $=$ & $a$ \\
\hline Kidney & $=$ & $\downarrow$ & & $=$ & $=$ & $a$ & $=$ & $=$ & $a$ & $=$ & $=$ & $a$ & $=$ & $\downarrow$ & & $=$ & $\downarrow$ & & $=$ & $=$ & $a$ & $=$ & $=$ & $a$ \\
\hline Lung & $=$ & $\downarrow$ & & $=$ & $\downarrow$ & & $=$ & $=$ & $a$ & $\downarrow$ & $=$ & & $=$ & $\downarrow$ & & $=$ & $\downarrow$ & & $=$ & $=$ & $a$ & $=$ & $=$ & $a$ \\
\hline Heart & $=$ & $\downarrow$ & & $=$ & $\downarrow$ & & $=$ & $=$ & $a$ & $\downarrow$ & $=$ & & $=$ & $\downarrow$ & & $=$ & $\downarrow$ & & $=$ & $=$ & $a$ & $=$ & $=$ & $a$ \\
\hline Spleen & $=$ & $\downarrow$ & & $=$ & $=$ & $a$ & $=$ & $\downarrow$ & & $=$ & $=$ & $a$ & $=$ & $\downarrow$ & & $=$ & $=$ & $a$ & $=$ & $=$ & & $=$ & $=$ & $a$ \\
\hline Muscle & $=$ & $\downarrow$ & & $=$ & $=$ & $a$ & $=$ & $=$ & $a$ & $=$ & $\uparrow$ & & $=$ & $\downarrow$ & & $=$ & $=$ & $a$ & $=$ & $=$ & $a$ & $=$ & $=$ & $a$ \\
\hline Adrenal & $\uparrow$ & $\downarrow$ & & $\downarrow$ & $=$ & & $\downarrow$ & $=$ & & $\downarrow$ & $=$ & & $=$ & $=$ & $a$ & $\uparrow$ & $=$ & & $=$ & $=$ & $a$ & $=$ & $\uparrow$ & \\
\hline Ovary & $=$ & $\downarrow$ & & $=$ & $=$ & $a$ & $=$ & $=$ & $a$ & $=$ & $=$ & $a$ & $=$ & $\downarrow$ & & $=$ & $=$ & $a$ & $=$ & $=$ & & $\downarrow$ & $=$ & \\
\hline
\end{tabular}

$\mathrm{T}_{4}$ and $\mathrm{T}_{3}$ doses were administered as micrograms per $100 \mathrm{~g}$ per day. The symbols represent the comparison of the mean values of the thyroidectomized rats infused with different doses of levothyroxine, alone or in combination with different doses of liothyronine, with control rats infused with placebo. $=$, No statistically significant differences; $\downarrow$, low levels as compared with controls, with at least $P<0.05$; $\uparrow$, elevated levels as compared with controls, with at least $P<0.05$. BAT, Brown adipose tissue. [Represented with permission from data published in $\mathrm{H}$. F. Escobar-Morreale et al.: Endocrinology 137:2490, 1996 (11). ${ }^{\odot}$ The Endocrine Society.]

${ }^{a}$ In addition to normal $\mathrm{T}_{4}$ and $\mathrm{T}_{3}$ concentrations, the molar $\mathrm{T}_{3}: \mathrm{T}_{4}$ ratio was not different from that in the control group.

a fixed amount of the daily levothyroxine dose, irrespective of total levothyroxine dose received by the patient. For 5-wk periods, patients received their usual levothyroxine dose, or a combination in which $50 \mu \mathrm{g}$ levothyroxine was withdrawn and $12.5 \mu \mathrm{g}$ liothyronine added. Although the order of treatments was randomized, the groups starting on the combination had normal mean TSH values, whereas those starting on levothyroxine alone had mean TSH values below the normal range. The levothyroxine doses ranged from 100-300 $\mu \mathrm{g} / \mathrm{d}$, with a mean $\pm \mathrm{sD}$ of $175 \pm 53 \mu \mathrm{g} / \mathrm{d}$. Therefore, $T_{3}$ was not in an enteric sustained-release form, and the molar $\mathrm{T}_{4}: \mathrm{T}_{3}$ ratios of the combinations received by the patients were quite variable, ranging from 3.4:1 (4:1 by wt) to 17:1 (20:1 by wt).

Despite the marked variability in prestudy levothyroxine doses and serum TSH levels and in the $\mathrm{T}_{4}: \mathrm{T}_{3}$ ratios of the combinations actually administered, Bunevicius et al. (30) found that the combinations of levothyroxine plus liothyronine improved several indexes of quality of life (QoL), mood, and psychometric performance (30). Patients preferred levothyroxine plus liothyronine combinations compared with replacement with levothyroxine alone (30). However, it should be noted that the statistical analysis applied in this study did not facilitate any information about possible period and sequence effects.

A subsequent reanalysis of the data, removing from the initial study the data from the two men, from four depressed women, and from a woman who presented with increased serum TSH levels at baseline, revealed that the findings originally reported were maintained only in the subset of athyreotic patients and not in women with autoimmune thyroiditis (32). This was unexpected, because the presumed benefits of $T_{3}$ substitution were restricted to athyreotic thyroid cancer patients, who had received proportionally less liothyronine than patients with autoimmune thyroiditis. In the subset of thyroid cancer patients, however, $\mathrm{T}_{3}$ substitution actually decreased the overall thyroid hormone dose, and the recovery from an iatrogenic thyrotoxic state might account for the improvement in QoL, similar to that occurring soon after levothyroxine withdrawal in thyroid cancer patients (33).

In a later study, Bunevicius et al. (34) tried to reproduce their initial results in a sample of 10 patients thyroidectomized for Graves' disease, but no improvements were found with $\mathrm{T}_{3}$ substitution. However, the very small sample size in this study precludes a definite conclusion.

The publication of the first study of Bunevicius et al. (30, 32) was greeted with considerable interest not only for scientific reasons but also for hypothyroid patients; combined levothyroxine plus liothyronine replacement was considered the answer to the relatively frequent complaint (35) of the persistence, with levothyroxine alone, of hypothyroid symptoms despite normalization of serum TSH.

To date, four published studies (36-39) have tried to reproduce the beneficial effects of $T_{3}$ substitution described above, without success (Table 4). Walsh et al. (36) conducted a randomized, double-blinded, crossover trial in which patients were treated with their usual levothyroxine dose or a combination that contained $50 \mu \mathrm{g}$ less of levothyroxine plus $10 \mu \mathrm{g}$ liothyronine for $10 \mathrm{wk}$, separated by a 4 -wk washout period on levothyroxine alone. Evaluation of the 101 patients completing the study revealed no substantial improvement in indexes of QoL, cognitive function, mood, or hypothyroid symptoms, and patients' preference was equal for both treatments (36). However, it should be noted that serum TSH levels were higher during $T_{3}$ substitution, and any possible improvement might have been obscured by a relative undertreatment of the patients (40).

Sawka et al. (37) evaluated the possible beneficial effects of $\mathrm{T}_{3}$ substitution in hypothyroid patients presenting with persistent depressive symptoms despite adequate replacement with levothyroxine alone. Using a randomized parallel design, 20 patients were assigned to continue with their usual 


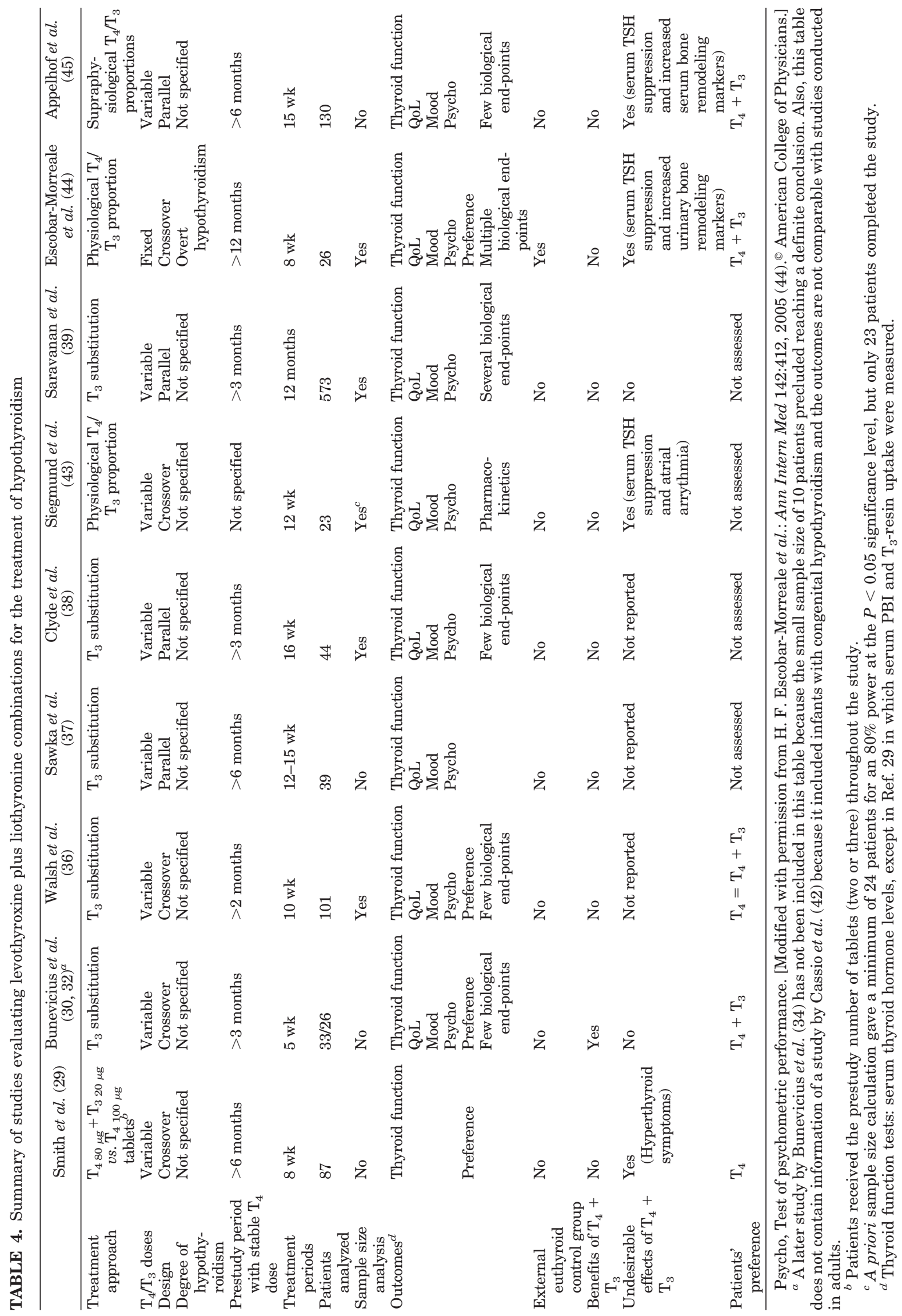



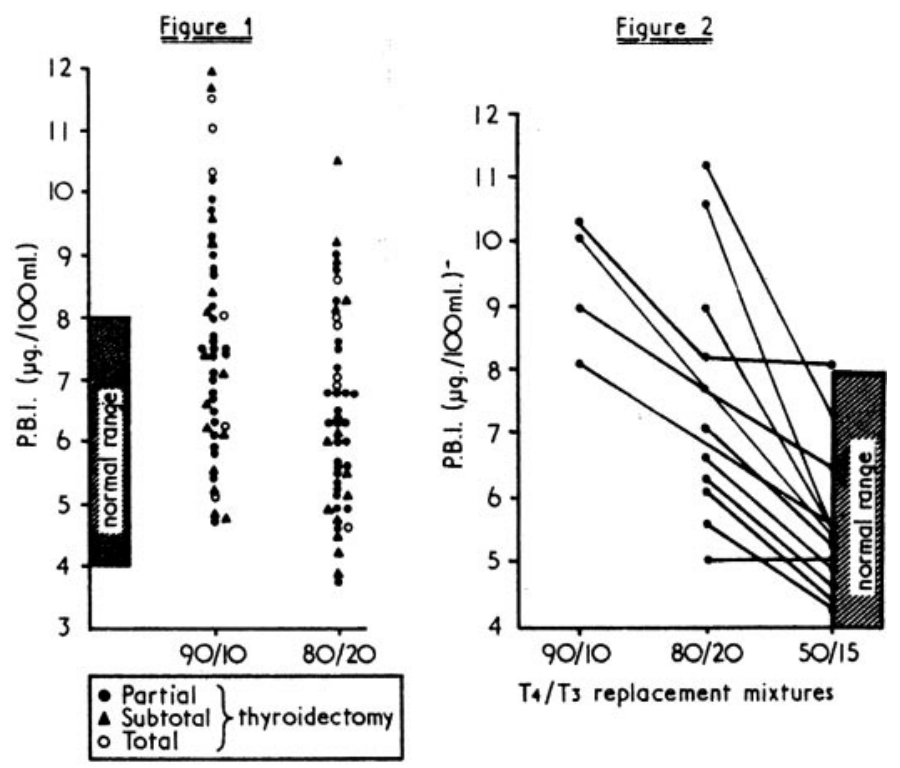

FIG. 2. Plasma PBI values in hypothyroid patients on different combinations of levothyroxine plus liothyronine. [Reproduced with permission from S. Taylor et al.: Br Med J 1:270, 1970 (28). (C) BMJ Publishing Group.]

levothyroxine dose, and another 20 patients received half their usual levothyroxine dose plus $12.5 \mu \mathrm{g}$ liothyronine twice daily (37). The liothyronine dose was titrated thereafter to maintain serum TSH concentrations within the normal range. Both treatments were maintained for $15 \mathrm{wk}$. Patients' preference was not assessed. No improvement of mood or hypothyroid symptoms was found with $\mathrm{T}_{3}$ substitution. A significant proportion of dropouts had occurred in both arms of treatment and a significant placebo effect detected (symptoms were ameliorated with both treatments). More importantly, power analysis was not provided despite the small sample size.

Clyde et al. (38) used a randomized parallel design to evaluate $T_{3}$ substitution that did not use a crossover design eliminating the possibility of a practice effect on the tests used for psychometric performance. In this study, $7.5 \mu \mathrm{g}$ liothyronine was given twice daily, and $50 \mu \mathrm{g}$ of their levothyroxine dose withdrawn for $16 \mathrm{wk}$ in the patients assigned to this arm of treatment. Although supported by adequate statistical power, results from the 44 patients completing the follow-up did not show any beneficial effect of $T_{3}$ substitution on psychometric performance, QoL, mood, and a few biological end-points of thyroid hormone action. Patients' preference was not evaluated.

Saravanan et al. (39) used $10 \mu \mathrm{g}$ liothyronine to substitute $50 \mu \mathrm{g}$ of the usual levothyroxine dose of the patients in a parallel randomized design including 697 patients. The main outcome was psychiatric caseness, defined by the General Health Questionnaire 12 score. They found a large and persisting placebo effect in the control group but only a minor improvement after 3 months of combined treatment, not sustained thereafter.

Considering the four negative studies published after the initial report by Bunevicius et al. $(30,32)$, it would appear that $\mathrm{T}_{3}$ substitution has a minor role, if any, in thyroid replace- ment therapy $(14,31,41)$. But this did not necessarily exclude a role of combinations of levothyroxine plus liothyronine in thyroid replacement therapy, because of important limitations of the $\mathrm{T}_{3}$ substitution approach: 1) considering that the prestudy levothyroxine requirements were quite variable in the patients recruited for these studies, this design resulted in a large variation in the $T_{4}: T_{3}$ ratios and in the absolute amounts of both iodothyronines, making it impossible to mimic normal thyroid physiology $(14,31,41) ; 2)$ these studies included both men and women, and gender might influence the response to treatment, especially in terms of mood and QoL; and 3) the previous duration and severity of hypothyroidism were quite variable, including patients presenting at diagnosis with subclinical hypothyroidism, who might retain some residual secretion of both $\mathrm{T}_{4}$ and $\mathrm{T}_{3}$. Therefore, the lack of beneficial effects of $\mathrm{T}_{3}$ substitution over levothyroxine alone might depend on these confounding factors and not on the lack of an overall beneficial effect of combined levothyroxine plus liothyronine replacement therapy.

Four very recent studies (Table 4), including one from our group, have further contributed to this issue (42-45). Cassio et al. (42) compared seven infants with congenital hypothyroidism treated with levothyroxine alone with seven infants treated with a levothyroxine plus liothyronine combination in a molar $\mathrm{T}_{4}: \mathrm{T}_{3}$ ratio of 17:1. The levothyroxine dose was reduced by $20 \%$ in the following combination: every $25 \mu \mathrm{g}$ of the levothyroxine dose calculated for body weight was substituted by $20 \mu \mathrm{g}$ levothyroxine plus $1 \mu \mathrm{g}$ liothyronine. Psychomotor development at 6 and 12 months was similarly impaired with both treatments when compared with euthyroid controls. Treatment adjustments based on serum TSH were more difficult with the combination and more frequently needed.

Siegmund et al. (43) conducted a crossover trial in which 26 hypothyroid patients were treated for 12 -wk periods either with their usual levothyroxine doses or with a combination of levothyroxine plus liothyronine. The latter had a 16:1 molar ratio, and under the assumption that bioavailability of oral liothyronine is $100 \%$, and that of levothyroxine is $90 \%$, the authors hypothesize a $14: 1$ bioavailable molar ratio. No improvement of well-being and cognitive performance was found with the combination, but the number of patients completing the study was insufficient to achieve statistical power (43). No changes were observed in serum free $T_{4}$ and free $T_{3}$, whereas TSH levels were more suppressed with the levothyroxine plus liothyronine combination, and in eight of the 23 patients analyzed, TSH was undetectable and associated with an impairment in mood indexes. Of note, one of the three patients not completing the study was removed during levothyroxine plus liothyronine combination treatment because of atrial fibrillation associated with suppression of TSH. The occurrence of this severe adverse event raises a cautionary note regarding the addition to levothyroxine of even very small quantities of liothyronine.

We have published recently a randomized, doubleblinded, crossover clinical trial comparing treatment with $100 \mu \mathrm{g}$ levothyroxine with a combination containing $75 \mu \mathrm{g}$ levothyroxine plus $5 \mu \mathrm{g}$ liothyronine per day (13:1 molar $\mathrm{T}_{4}: \mathrm{T}_{3}$ ratio, $15: 1$ by $\mathrm{wt}$ ). However, fearing possible undertreatment, all the patients were given, for a final 8-wk add-on 
period, a combination containing $87.5 \mu \mathrm{g}$ levothyroxine plus $7.5 \mu \mathrm{g}$ liothyronine per day $\left(10: 1\right.$ molar $\mathrm{T}_{4}: \mathrm{T}_{3}$ ratio, $12: 1$ by wt).

We also tried to overcome most of the limitations of previous studies (Table 4 ) by using two fixed combinations of levothyroxine plus liothyronine, in proportions based on those secreted by the normal thyroid, thus avoiding the variable and excessive amounts of liothyronine compared with that of levothyroxine used before.

To avoid heterogeneity, we included only female patients who had long-term overt primary hypothyroidism, making any interference from residual thyroid function unlikely, and who had been treated with a $100 \mu \mathrm{g} / \mathrm{d}$ dose of levothyroxine for at least 1 yr before recruitment. Outcomes were not restricted to QoL and psychometric functionality but consisted in a broad evaluation of thyroid hormone biological endpoints covering most organs and systems. And finally, only our study included an external control group of healthy euthyroid women, allowing us to evaluate whether the measured outcomes were affected in the hypothyroid patients irrespective of treatment protocol, thus eliminating a potential confounding factor in previous studies.

Given these strict inclusion criteria, we were able to recruit only 28 women, of whom 26 completed the study. Yet power analysis indicated that this sample size was enough to detect the differences in the QoL, mood, and psychometric indexes previously reported by Bunevicius et al. $(30,32)$. Twenty healthy women served as euthyroid controls.

After treatment with the combination of $75 \mu \mathrm{g}$ levothyroxine plus $5 \mu \mathrm{g}$ liothyronine, serum free $\mathrm{T}_{4}$ levels decreased as compared with levothyroxine alone, whereas TSH increased slightly and free $\mathrm{T}_{3}$ remained unchanged (Fig. 3). On the contrary, the $87.5 \mu \mathrm{g}$ levothyroxine plus $7.5 \mu \mathrm{g}$ liothyronine combination resulted in over-replacement, given that

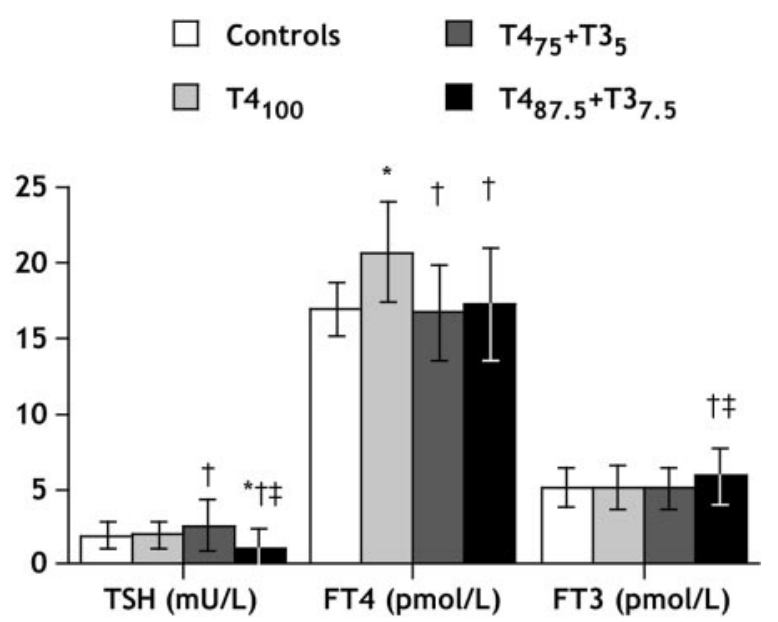

Fig. 3. Serum TSH, free $\mathrm{T}_{4}$ (FT4), and free $\mathrm{T}_{3}$ (FT3) concentrations in patients treated with $100 \mu \mathrm{g} / \mathrm{d}$ levothyroxine alone $\left(\mathrm{T} 4_{100}\right), 75 \mu \mathrm{g}$ of levothyroxine plus $5 \mu \mathrm{g}$ of liothyronine per day $\left(\mathrm{T} 4_{75}+\mathrm{T} 3_{5}\right)$, or 87.5 $\mu \mathrm{g}$ levothyroxine plus $7.5 \mu \mathrm{g}$ liothyronine per day $\left(\mathrm{T} 4_{87.5}+\mathrm{T} 3_{7.5}\right.$ ), compared with euthyroid controls. Data are means \pm SD. ${ }^{*}, P<0.05$ compared with euthyroid controls; $\uparrow, P<0.05$ compared with T4 $4_{100}$; $\ddagger, P<0.05$ compared with $\mathrm{T} 4_{75}+\mathrm{T} 3_{5}$. [Redrawn with permission from H. F. Escobar-Morreale et al.: Ann Intern Med 142:412, 2005 (44). (C) American College of Physicians.]
TSH levels decreased and free $\mathrm{T}_{3}$ increased compared with levothyroxine alone (Fig. 3), and in 10 of the patients TSH levels were below the lower limit of the normal range (but not suppressed).

We were not able to demonstrate any significant improvement in QoL, mood, or psychometric indexes (44). Patients scored better in only a few indexes of psychometric performance after receiving the combination containing $87.5 \mu \mathrm{g}$ levothyroxine plus $7.5 \mu \mathrm{g}$ liothyronine, although this slight improvement might have resulted from overtreatment rather than from the combined therapy. Of note, our statistical analysis ruled out any significant period or sequence effect on the psychometric tests, making significant practice effects unlikely.

In fact, some items were worse in patients than in euthyroid controls, independently of the treatment they received. As previous studies have shown for hypothyroid patients on levothyroxine alone (35), it is possible that being aware of having a disease accounts for this difference (46).

We did not find any improvement in biological end-points pertaining to multiple organs and systems, including anthropometrical, biochemical, hormonal, neurological, and echocardiographic outcomes. Yet it is important to highlight that both combinations of levothyroxine plus liothyronine undesirably increased the urinary concentrations of boneremodeling markers.

Patients, however, actually preferred the combinations. Of the 26 patients, 12 preferred the combination of $75 \mu \mathrm{g}$ levothyroxine plus $5 \mu \mathrm{g}$ liothyronine, six preferred $87.5 \mu \mathrm{g}$ levothyroxine plus $7.5 \mu \mathrm{g}$ liothyronine, two preferred levothyroxine alone, and six showed no preference. Although it might be argued that patients preferred the $87.5 \mu \mathrm{g}$ levothyroxine plus $7.5 \mu \mathrm{g}$ liothyronine combination because of over-replacement, it should be highlighted that most patients preferred the $75 \mu \mathrm{g}$ levothyroxine plus $5 \mu \mathrm{g}$ liothyronine combination, which resulted in the mild under-replacement suggested by slightly increased TSH and cholesterol values.

This preference for the combined therapy might have resulted from chance. But patients in the Bunevicius et al. (30) study also preferred levothyroxine plus liothyronine combinations, and a similar result has been recently confirmed in a large study conducted in The Netherlands by Appelhof et al. (45). One hundred forty-one hypothyroid patients were randomized to continue on levothyroxine alone, on a combination of levothyroxine plus liothyronine in a molar $\mathrm{T}_{4}: \mathrm{T}_{3}$ ratio of $4.2: 1$ (5:1 by wt), or on combination in a molar $\mathrm{T}_{4}: \mathrm{T}_{3}$ ratio of $8.4: 1$ (10:1 by wt), for $15 \mathrm{wk}$. The primary outcome of this trial was patients' preference, and indexes pertaining to mood, well-being, and fatigue were considered secondary outcomes. Study medication was preferred to usual treatment by $29.2 \%$ in the levothyroxine group, $41.3 \%$ in the $10: 1$ ratio group, and $52.2 \%$ in the 5:1 ratio group. Serum TSH and body weight decreased with the combinations, especially with that containing a $T_{4}: T_{3}$ ratio of $5: 1$ with which TSH was actually suppressed in many subjects, as indicated by median values of $0.07 \mu \mathrm{U} / \mathrm{ml}$. As occurred in our study (44), the psychological tests used in the Dutch study (45) did not show any improvement with the levothyroxine plus liothyronine combinations, and only a minimal reduction in body weight 
was found (mean loss of 0.5 and $1.7 \mathrm{~kg}$ in $15 \mathrm{wk}$ with the $10: 1$ and 5:1 combinations, respectively).

Although most of the limitations of the studies by Smith et al. (29) and Bunevicius et al. (30) have later been addressed, the $\mathrm{T}_{3}$ preparation used in all of them was liothyronine, because at present no sustained-release preparations are commercially available. For this reason, we were ourselves (44) unable to follow one of the recommendations emanating from our animal work (11).

Recently, Hennemann et al. (47) have reported a preliminary description of three 6-wk treatment periods of hypothyroid patients with their usual levothyroxine dose (150 $\mu \mathrm{g} / \mathrm{d}$ for most of them), followed by $6 \mathrm{wk}$ on a combination of $125 \mu \mathrm{g}$ levothyroxine plus $6 \mu \mathrm{g}$ liothyronine (in a molar $\mathrm{T}_{4}: \mathrm{T}_{3}$ ratio of $17: 1$ ) containing an in-house slow-release $\mathrm{T}_{3}$ preparation and $6 \mathrm{wk}$ on the same combination but using the Cytomel liothyronine commercial preparation. Lack of information on the actual chemical nature of the slow-release preparation precludes confirmation of their findings by others.

Compared with a similar combination in which $\mathrm{T}_{3}$ was standard liothyronine, the combination with the slow-release preparation decreased slightly the maximal serum $\mathrm{T}_{3}$ concentration attained and increased slightly the timing of maximal concentrations of serum $\mathrm{T}_{3}$ after ingestion, whereas the area under the curve of serum $\mathrm{T}_{3}$ remained unchanged (47).

Whether these small changes in the pharmacokinetics of this compound actually represent a major improvement is a matter of discussion (48), especially when considering that the mean serum $\mathrm{T}_{4}, \mathrm{~T}_{3}$, and TSH concentrations of the patients attained after the standard and after the slow-release $\mathrm{T}_{3}$ preparations were unchanged and that with the actual doses of levothyroxine plus liothyronine that were used, serum $\mathrm{T}_{4}$ concentration remained increased and the serum $\mathrm{T}_{3}$ levels remained low when compared with euthyroid controls, despite the decrease in TSH levels (47).

\section{Summary and Conclusions}

In humans, combined levothyroxine plus liothyronine treatment does not appear to have clear advantages over the standard treatment with levothyroxine alone. The initial report of beneficial effects of $\mathrm{T}_{3}$ substitution on mood, QoL, and psychometric functionality has not been confirmed by later studies, using both $\mathrm{T}_{3}$ substitution and physiological approaches to combined levothyroxine plus liothyronine replacement therapy.

However, in some of these studies, the patients preferred levothyroxine plus liothyronine combinations over levothyroxine alone, for reasons not explained by changes in the psychological and psychometric tests employed or the biological end-points that were also measured. Yet patients' preference should be balanced against the possibility of adverse events resulting from the addition of liothyronine to levothyroxine, even in the small doses used in these studies.

Therefore, until clear advantages of levothyroxine plus liothyronine are demonstrated, levothyroxine alone should remain the drug of choice for the replacement therapy of hypothyroidism.

\section{Acknowledgments}

Received January 27, 2005. Accepted May 20, 2005.

Address all correspondence and requests for reprints to: Héctor F. Escobar-Morreale, M.D., Ph.D., Department of Endocrinology, Hospital Ramón y Cajal, Carretera de Colmenar Km 9,100, 28034 Madrid, Spain. E-mail: hescobarm.hrc@salud.madrid.org.

This work was supported by Grant 01/0430/01 from the Consejería de Educación, Comunidad de Madrid (to J.I.B.-C.) and by grants from the Fondo de Investigación Sanitaria, Instituto de Salud Carlos III (01/ F072 to J.I.B.-C.; and RCMN 03/08 and PI 03/1417 to G.M.d.E.).

\section{References}

1. American Association of Clinical Endocrinologists 2002 American Association of Clinical Endocrinologists medical guidelines for clinical practice for the evaluation and treatment of hyperthyroidism and hypothyroidism. Endocr Pract 8:457-469

2. Ross DR 2004 Treatment of hypothyroidism. In: Snyder PJ, Utiger RD, eds. Up to date in endocrinology and diabetes. Wellesley, MA: UpToDate

3. Wiersinga WM 2004 Hypothyroidism. In: DeGroot LJ, Hennemann G, eds. Thyroid disease manager. Chicago: The University of Chicago Pritzker School of Medicine, Endocrine Education

4. Pilo A, Iervasi G, Vitek F, Ferdeghini M, Cazzuola F, Bianchi R 1990 Thyroidal and peripheral production of 3,5,3'-triiodothyronine in humans by multicompartmental analysis. Am J Physiol 258:E715-E726

5. Fish LH, Schwartz HL, Cavanaugh J, Steffes MW, Bantle JP, Oppenheimer JH 1987 Replacement dose, metabolism, and bioavailability of levothyroxine in the treatment of hypothyroidism. Role of triiodothyronine in pituitary feedback in humans. N Engl J Med 316:764-770

6. Utiger RD 1995 Hypothyroidism. In: De Groot LJ, ed. Endocrinology. 3rd ed. Philadelphia: WB Saunders; 752-768

7. Hennessey JV, Evaul JE, Tseng YC, Burman KD, Wartofsky L 1986 L-Thyroxine dosage: a reevaluation of therapy with contemporary preparations. Ann Intern Med 105:11-15

8. Gow SM, Caldwell G, Toft AD, Seth J, Hussey AJ, Sweeting VM, Beckett GJ 1987 Relationship between pituitary and other target organ responsiveness in hypothyroid patients receiving thyroxine replacement. J Clin Endocrinol Metab 64:364-370

9. De Groot L, Manowitz N, Chait L, Mayor G, Differential end organ responsiveness to suboptimal thyroid hormone concentrations as assessed by shortterm withdrawal of levothyroxine sodium in athyreotic patients. Proc 70th Annual Meeting of the American Thyroid Association, Colorado Springs, CO, 1997, p S-88

10. Escobar-Morreale HF, Obregón MJ, Escobar del Rey F, Morreale de Escobar G 1995 Replacement therapy for hypothyroidism with thyroxine alone does not ensure euthyroidism in all tissues, as studied in thyroidectomized rats. J Clin Invest 96:2828-2838

11. Escobar-Morreale HF, Escobar del Rey F, Obregón MJ, Morreale de Escobar G 1996 Only the combined treatment with thyroxine and triiodothyronine ensures euthyroidism in all tissues of the thyroidectomized rat. Endocrinology 137:2490-2502

12. Escobar-Morreale HF, Obregón MJ, Hernández A, Escobar del Rey F, Morreale de Escobar G 1997 Regulation of iodothyronine deiodinase activity as studied in thyroidectomized rats infused with thyroxine or triiodothyronine. Endocrinology 138:2559-2568

13. Escobar-Morreale HF, Obregon MJ, Escobar del Rey F, Morreale de Escobar G 1999 Tissue-specific patterns of changes in 3,5,3'-triiodo-L-thyronine concentrations in thyroidectomized rats infused with increasing doses of the hormone. Which are the regulatory mechanisms? Biochimie (Paris) 81:453-462

14. Toft AD 1999 Thyroid hormone replacement: one hormone or two? N Engl J Med 340:469-470

15. Schroder van der Elst JP, van der Heide D 1990 Effects of 5,5'-diphenylhydantoin on thyroxine and 3,5,3'-triiodothyronine concentrations in several tissues of the rat. Endocrinology 126:186-191

16. Schroder van der Elst JP, van der Heide D 1990 Thyroxine, 3,5,3'-triiodothyronine, and 3,3',5'-triiodothyronine concentrations in several tissues of the rat: effects of amiodarone and desethylamiodarone on thyroid hormone metabolism. Endocrinology 127:1656-1664

17. Schroder van der Elst JP, van der Heide D, Kohrle J 1991 In vivo effects of flavonoid EMD 21388 on thyroid hormone secretion and metabolism in rats. Am J Physiol 261:E227-E232

18. Schroder van der Elst JP, van der Heide D 1992 Effects of streptozocininduced diabetes and food restriction on quantities and source of $T_{4}$ and $T_{3}$ in rat tissues. Diabetes 41:147-152

19. Imamura S, Mori Y, Murata Y, Yamamori I, Miura Y, Oiso Y, Seo H, Matsui N, Refetoff S 1991 Molecular cloning and primary structure of rat thyroxinebinding globulin. Biochemistry 30:5406-5411

20. Tani Y, Mori Y, Miura Y, Okamoto H, Inagaki A, Saito H, Oiso Y 1994 
Molecular cloning of the rat thyroxine-binding globulin gene and analysis of its promoter activity. Endocrinology 135:2731-2736

21. Palha JA, Episkopou V, Maeda S, Shimada K, Gottesman ME, Saraiva MJ 1994 Thyroid hormone metabolism in a transthyretin-null mouse strain. J Biol Chem 269:33135-33139

22. Palha JA, Hays MT, Morreale de Escobar G, Episkopou V, Gottesman M, Saraiva MJM 1997 Transthyretin is not essential for thyroxine to reach the brain and other tissues in a transthyretin-null mouse. Am J Physiol 272:E485E493

23. Bianco AC, Salvatore D, Gereben B, Berry MJ, Larsen PR 2002 Biochemistry, cellular and molecular biology, and physiological roles of the iodothyronine selenodeiodinases. Endocr Rev 23:38-89

24. Oppenheimer JH, Schwartz HL 1985 Stereospecific transport of triiodothyronine from plasma to cytosol and from cytosol to nucleus in the rat liver, kidney, brain and heart. J Clin Invest 75:147-154

25. Oppenheimer JH, Schwartz HL, Mariash CN, Kinlaw WB, Feake HC 1987 Advances in our understanding of thyroid hormone action at the cellular level. Endocr Rev 8:288-306

26. Hennemann G, Docter R, Friesema EC, de Jong M, Krenning EP, Visser T 2001 Plasma membrane transport of thyroid hormones and its role in thyroid hormone metabolism and bioavailability. Endocr Rev 22:451-476

27. Larsen PR, Davies TF, Hay ID 1998 The thyroid gland. In: Wilson JD, Foster DW, Kronenberg HM, Larsen PR, eds. Williams textbook of endocrinology. 9th ed. Philadelphia: WB Saunders; 389-396

28. Taylor S, Kapur M, Adie R 1970 Combined thyroxine and triiodothyronine for thyroid replacement therapy. Br Med J 1:270-271

29. Smith RN, Taylor SA, Massey JC 1970 Controlled clinical trial of combined triiodothyronine and thyroxine in the treatment of hypothyroidism. Br Med J 4:145-148

30. Bunevicius R, Kazanavicius G, Zalinkevicius R, Prange Jr AJ 1999 Effects of thyroxine as compared with thyroxine plus triiodothyronine in patients with hypothyroidism. N Engl J Med 340:424-429

31. Kaplan MM, Sarne DH, Schneider AB 2003 In search of the impossible dream? Thyroid hormone replacement therapy that treats all symptoms in all hypothyroid patients. J Clin Endocrinol Metab 88:4540-4542

32. Bunevicius R, Prange Jr AJ 2000 Mental improvement after replacement therapy with thyroxine plus triiodothyronine: relationship to cause of hypothyroidism. Int J Neuropsychopharmacol 3:167-174

33. Botella-Carretero JI, Galán JM, Caballero C, Sancho J, Escobar-Morreale HF 2003 Quality of life and psychometric functionality in patients with differentiated thyroid carcinoma. Endocr Relat Cancer 10:601-611

34. Bunevicius R, Jakubonien N, Jurkevicius R, Cernicat J, Lasas L, Prange Jr AJ 2002 Thyroxine vs thyroxine plus triiodothyronine in treatment of hypothyroidism after thyroidectomy for Graves' disease. Endocrine 18:129-133

35. Saravanan P, Chau WF, Roberts N, Vedhara K, Greenwood R, Dayan CM 2002 Psychological well-being in patients on 'adequate' doses of L-thyroxine: results of a large, controlled community-based questionnaire study. Clin Endocrinol (Oxf) 57:577-585
36. Walsh JP, Shiels L, Lim EM, Bhagat CI, Ward LC, Stuckey BGA, Dhaliwal SS, Chew GT, Bhagat MC, Cussons AJ 2003 Combined thyroxine/liothyronine treatment does not improve well-being, quality of life, or cognitive function compared to thyroxine alone: a randomized controlled trial in patients with primary hypothyroidism. J Clin Endocrinol Metab 88:4543-4550

37. Sawka AM, Gerstein HC, Marriot MJ, MacQueen GM, Joffe RT 2003 Does a combination regimen of thyroxine $\left(\mathrm{T}_{4}\right)$ and 3,5,3'-triiodothyronine improve depressive symptoms better than $\mathrm{T}_{4}$ alone in patients with hypothyroidism? Results of a double-blind, randomized, controlled trial. J Clin Endocrinol Metab 88:4551-4555

38. Clyde PW, Harari AE, Getka EJ, Shakir KM 2003 Combined levothyroxine plus liothyronine compared with levothyroxine alone in primary hypothyroidism: a randomized controlled trial. JAMA 290:2952-2958

39. Saravanan P, Simmons DJ, Greenwood R, Peters TJ, Dayan CM 2005 Partial substitution of thyroxine $\left(\mathrm{T}_{4}\right)$ with tri-iodothyronine in patients on $\mathrm{T}_{4}$ replacement therapy: results of a large community-based randomized controlled trial. J Clin Endocrinol Metab 90:805-812

40. Carr D, McLeod DT, Parry G, Thornes HM 1988 Fine adjustment of thyroxine replacement dosage: comparison of the thyrotrophin releasing hormone test using a sensitive thyrotrophin assay with measurement of free thyroid hormones and clinical assessment. Clin Endocrinol (Oxf) 28:325-333

41. Cooper DS 2003 Combined $\mathrm{T}_{4}$ and $\mathrm{T}_{3}$ therapy: back to the drawing board. JAMA 290:3002-3004

42. Cassio A, Cacciari E, Cicognani A, Damiani G, Missiroli G, Corbelli E, Balsamo A, Bal M, Gualandi S 2003 Treatment for congenital hypothyroidism: thyroxine alone or thyroxine plus triiodothyronine? Pediatrics 111:1055-1060

43. Siegmund W, Spieker K, Weike AI, Giessmann T, Modess C, Dabers T, Kirsch G, Sanger E, Engel G, Hamm AO, Nauck M, Meng W 2004 Replacement therapy with levothyroxine plus triiodothyronine (bioavailable molar ratio 14:1) is not superior to thyroxine alone to improve well-being and cognitive performance in hypothyroidism. Clin Endocrinol (Oxf) 60:750-757

44. Escobar-Morreale HF, Botella-Carretero JI, Gomez-Bueno M, Galan JM, Barrios V, Sancho J 2005 Thyroid hormone replacement therapy in primary hypothyroidism: a randomized trial comparing L-thyroxine plus liothyronine with L-thyroxine alone. Ann Intern Med 142:412-424

45. Appelhof BC, Fliers E, Wekking EM, Schene AH, Huyser J, Tijssen JG, Endert E, van Weert HC, Wiersinga WM 2005 Combined therapy with levothyroxine and liothyronine in two ratios, compared with levothyroxine monotherapy in primary hypothyroidism: a double-blind, randomized, controlled clinical trial. J Clin Endocrinol Metab 90:2666-2674

46. Ladenson PW 2002 Psychological wellbeing in patients. Clin Endocrinol (Oxf) 57:575-576

47. Hennemann G, Docter R, Visser TJ, Postema PT, Krenning EP 2004 Thyroxine plus low-dose, slow-release triiodothyronine replacement in hypothyroidism: proof of principle. Thyroid 14:271-275

48. Wartofsky L 2004 Combined levotriiodothyronine and levothyroxine therapy for hypothyroidism: are we a step closer to the magic formula? Thyroid $14: 247-248$

JCEM is published monthly by The Endocrine Society (http://www.endo-society.org), the foremost professional society serving the endocrine community. 